\title{
Expression profiling of tomato pre-abscission pedicels provides insights into abscission zone properties including competence to respond to abscission signals
}

Toshitsugu Nakano, Masaki Fujisawa, Yoko Shima and Yasuhiro Ito

\begin{abstract}
Background: Detachment of plant organs occurs in abscission zones (AZs). During plant growth, the AZ forms, but does not develop further until the cells perceive abscission-promoting signals and initiate detachment. Upon signal perception, abscission initiates immediately; if there is no signal, abscission is not induced and the organ remains attached to the plant. However, little attention has been paid to the genes that maintain competence to respond to the abscission signal in the pre-abscission AZ. Recently, we found that the tomato (Solanum lycopersicum) transcription factors BLIND (BI), GOBLET (GOB), Lateral suppressor (LS) and a tomato WUSCHEL homologue (LeWUS) are expressed specifically in pre-abscission tissue, the anthesis pedicel AZs. To advance our understanding of abscission, here we profiled genome-wide gene expression in tomato flower pedicels at the pre-abscission stage.

Results: We examined the transcriptomes of three tomato flower pedicel regions, the AZ and flanking proximal(Prox) and distal- (Dis) regions, and identified 89 genes that were preferentially expressed in the AZ compared to both Prox and Dis. These genes included several transcription factors that regulate apical or axillary shoot meristem activity. Also, genes associated with auxin activity were regulated in a Prox-Dis region-specific manner, suggesting that a gradient of auxin exists in the pedicel. A MADS-box gene affecting floral transition was preferentially expressed in the Prox region and other MADS-box genes for floral organ identification were preferentially expressed in Dis, implying that the morphologically similar Prox and Dis regions have distinct identities. We also analyzed the expression of known regulators; in anthesis pedicels, BI, GOB, LS and LeWUS were expressed in the vascular cells of the AZ region. However, after an abscission signal, B/ was up-regulated, but GOB, Ls and LeWUS were downregulated, suggesting that $B /$ may be a positive regulator of abscission, but the others may be negative regulators.
\end{abstract}

Conclusions: This study reveals region-specific gene expression in tomato flower pedicels at anthesis and identifies factors that may determine the physiological properties of the pre-abscission pedicel. The region-specific transcriptional regulators and genes for auxin activity identified here may prevent flower abscission in the absence of signal or establish competence to respond to the abscission signal.

Keywords: Tomato (Solanum lycopersicum), Abscission zone, Flower pedicel, Auxin, Shoot meristem, Competence to respond to abscission signals, Transcription factor, MADS-box genes

\footnotetext{
*Correspondence: yasuito@affrc.go.jp

Food Biotechnology Division, National Food Research Institute, NARO, 2-1-12 Kannondai, Tsukuba, Ibaraki 305-8642, Japan
} 


\section{Background}

Plants can detach aged leaves, unfertilized flowers, diseased or damaged organs and mature fruits or ripe seeds. These abscission processes enable plants to recycle nutrients for continuous growth, develop appropriate organs, survive diseases, and facilitate reproduction $[1,2]$. Abscission occurs at predetermined positions called abscission zones (AZs). The AZ contains a group of small cells that lack large vacuoles, suggesting that these cells may be arrested in an undifferentiated state [3]. Control of abscission has been an important agricultural concern because of its substantial effect on crop yield and quality. For example, humans have selected germplasms with reduced seed shattering during the domestication of grains such as rice (Oryza sativa), maize (Zea mays), and wheat (Triticum aestivum) [4-6]. Also, in tomato (Solanum lycopersicum), "jointless" cultivars with mutations inhibiting pedicel AZ development have been widely adopted for mechanical harvesting, because in the absence of an AZ, the stem and sepals remain on the plant, allowing the fruit to be harvested without the green tissues.

Abscission can be divided into four major steps [7]: (1) development of the AZ, (2) acquisition of competence to respond to abscission-promoting signaling, (3) activation of abscission, and (4) sealing of the break by differentiation of a protective layer on the main body side of the AZ. AZ development in tomato fruit/flower pedicels has been extensively investigated and several mutations that affect pedicel AZ development have been identified. For example, jointless $(j)$ and jointless 2 (j2) mutations completely suppress AZ differentiation and the lateral suppressor $(l s)$ mutation partially impairs AZ development [1,8-10]. The $j$ and $l s$ loci encode a MADS-box transcription factor and a GRAS family transcription factor, respectively $[11,12]$. The $j 2$ locus remains to be identified but is predicted to encode a C-terminal domain (CTD) phosphatase-like protein [13]. Recently, we determined that the MADS-box transcription factor MACRO CALYX (MC), which was identified as a regulator of sepal size [14], also regulates tomato pedicel AZ development by interacting with the MADS-box protein encoded by the $j$ locus [10].

In other systems, investigation of genes involved in $\mathrm{AZ}$ structure development (step1) identified several genes regulating the formation of the AZ. In Arabidopsis, the MADS-box transcription factor gene SEEDSTICK (STK) and the bHLH transcription factor gene HECATE3 (HEC3) regulate the formation of seed AZs [15,16], and $B L A D E-O N-P E T I O L E 1$ (BOP1) and BOP2, which encode $\mathrm{BTB} / \mathrm{POZ}$ domain and ankyrin repeat containing NPR1like proteins, regulate formation of floral organ AZs [17]. In rice, pedicel $A Z$ formation for seed shattering is regulated by $q S H 1$, which is a major chromosome 1 quantitative trait locus for seed shattering and encodes a BELL-type homeobox transcription factor, and $\mathrm{SH} 4$, which is a major chromosome 4 seed shattering quantitative trait locus and encodes a MYB3 DNA-binding domain containing protein. Rice pedicel AZ formation is also regulated by SHATTERING ABORTION1 (SHAT1) encoding an AP2 family transcription factor, the rice SHATTERING1 homologue (OsSH1) encoding a YAB family transcription factor, and CTD phosphatase-like protein1 (OsCPL1) [6,18-21].

Studies of steps 3 and 4, activation of abscission and differentiation of the protective layer, have also revealed several factors required for abscission. For example, the phytohormones auxin and ethylene stimulate abscissionpromoting signaling and regulate the onset of abscission in an antagonistic fashion; auxin inhibits the onset of abscission and ethylene promotes abscission [1,2,22]. Cell wall degrading and modifying enzymes are activated in the AZ separation layers [23-26]. In addition, transcription factors, receptor-like kinases, signal peptides, chromatin remodeling factors and membrane-trafficking proteins are involved in the activation of abscission [24]. Furthermore, genome-wide transcriptome analyses revealed that a wide variety of genes for phytohormone signaling, cell wall degradation, and defense related proteins are up-regulated during abscission [27-29].

Although many studies have examined the other steps of abscission, the mechanisms that drive step 2, acquisition of competence to respond to abscission signals, have remained mysterious. Prior to the onset of abscission, AZs possess the ability to respond to abscissioninitiating signaling but the AZ cells have not initiated abscission. For example, tomato pedicel AZs at anthesis remain in an idling state before receiving abscissionpromoting signals. Once the signal is provided, the AZ cells immediately start abscission, but if the flower is successfully pollinated, then the AZ cells remain small, dividing as the $\mathrm{AZ}$ structure grows thicker to support the growing fruit. The cells in stage 2 are seemingly static and inactive, but we recently found that AZs of tomato pedicels at anthesis show a distinct gene expression pattern; the anthesis pedicel AZs specifically express BLIND $(B l), G O B L E T(G O B), L s$ and a tomato WUSCHEL homologue (LeWUS), and this expression is not present in the pedicels of AZ-lacking mutants [10]. The function of these transcription factor genes in pedicel AZs is still unknown, but these genes are well known to play crucial roles in shoot apical or axillary meristems [10,12,30-32]. Their AZ-specific expression suggests that these transcription factors may act at the pre-abscission step, possibly to prevent flower abscission or to establish competence to respond to abscission signaling. 
To identify additional genes potentially involved in the abscission of tomato pedicels at anthesis, here we performed transcriptome analyses comparing the expression profiles in AZs with two flanking pedicel regions, on the flower side (distal region; Dis) and on the inflorescence side (proximal region; Prox, Figure 1A). Examination of the specific expression properties of these pedicel regions provided insights on the properties of each pedicel region and on cell activity in the preabscission state. In addition, we further characterized four previously identified transcription factors, examining the detailed expression patterns of LeWUS, Bl, GOB and $L s$ at anthesis. Our results indicated that these four genes showed significant expression changes when abscission was induced, suggesting that these genes play pivotal roles in the onset of abscission.

\section{Results}

Comparative transcriptome analysis revealed genes upregulated in the $A Z$ of tomato flower pedicels at anthesis AZ cells of a tomato flower are recognized even at the early stage of flower primordium development; at the flower anthesis stage, six to eight layers of cells are observed in the AZ and the flower pedicels have acquired the competence to respond to abscission-promoting signals $[27,33,34]$. To identify genes preferentially expressed in the $\mathrm{AZ}$ of tomato flower pedicels at anthesis, we used the Agilent tomato $44 \mathrm{~K}$ oligonucleotide DNA microarray to perform transcriptome assays comparing AZs and the non-AZ pedicel regions, Dis and Prox (Figure 1A). Microarray experiments were performed on three independently prepared samples and probes showing at least a 3 -fold change $(p<0.05)$ in signal intensity were selected.

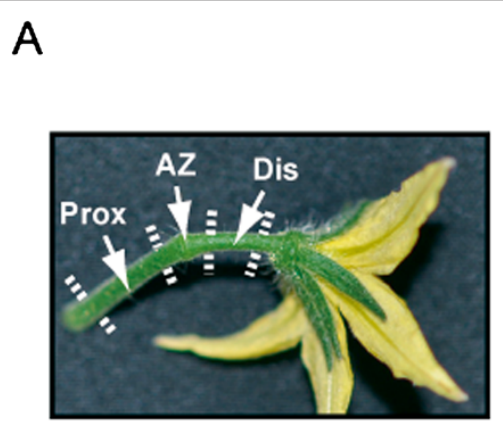

B

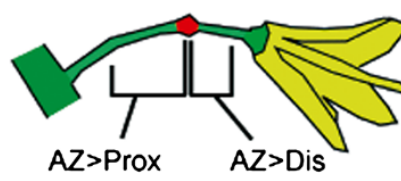

(426 probes) (319 probes)

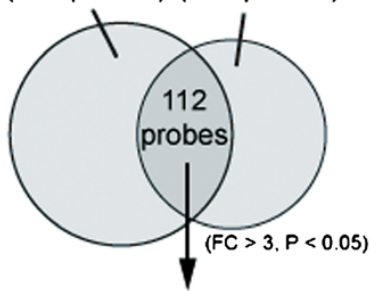

89 independent genes

C
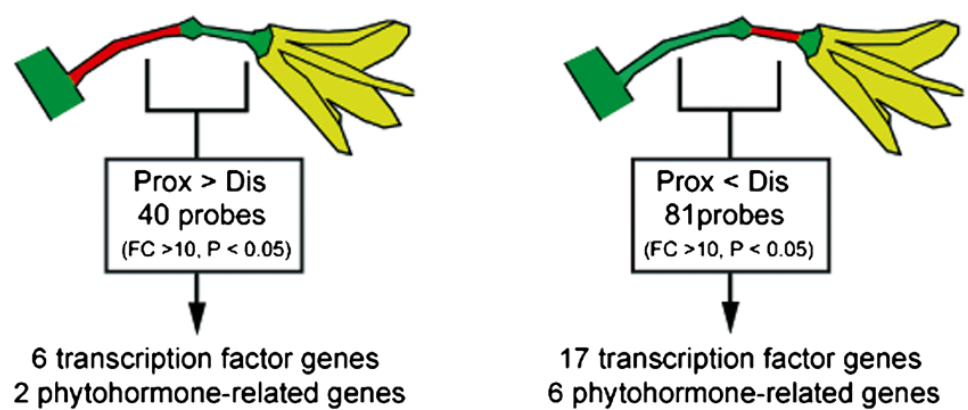

17 transcription factor genes

6 phytohormone-related genes

Figure 1 Screening for genes differentially expressed in different tomato pedicel regions by expression microarray analysis. (A) Flower pedicel regions used in this study. Tomato abscission zones (AZs) form in an intermediate region in the pedicels and have a knuckle-like structure in which a groove forms for abscission. The pedicel region between the AZ and the main stem of the inflorescence is referred to as the proximal region (Prox) and the region between the AZ and the flower is referred to as the distal region (Dis). RNA from each region was extracted from five to twenty pedicels at anthesis. (B) A schematic of the genome-wide transcriptome screen for genes up-regulated in the AZ. Expression was compared between AZ and Prox or Dis at anthesis by microarray analyses with 3 independently prepared samples. Two circles in the Venn diagram indicate the number of probes showing higher signal from AZ than that from Prox or Dis, and the 112 probes in the overlap were further investigated in this study. By merging results for probes encoding the same gene, we found 89 independent genes up-regulated in the AZ. (C) A schematic of the screening for transcription factor and phytohormone-related genes differentially expressed between Prox and Dis. The expression profiles of Prox and Dis examined by microarray analyses were compared and genes for transcription factors or phytohormone-related activity were selected from the genes exhibiting significantly different expression patterns between the two regions. 
Table 1 Genes up-regulated in the tomato pedicel abscission zone (AZ) compared with the proximal (Prox) and distal (Dis) regions of the pedicel

\begin{tabular}{|c|c|c|c|c|c|c|c|c|}
\hline \multirow[b]{2}{*}{ Tomato Gene ID } & \multirow[b]{2}{*}{ Probe ID } & \multirow[b]{2}{*}{$\begin{array}{l}\text { Gene name / } \\
\text { EST accession } \\
\text { number }\end{array}$} & \multirow[b]{2}{*}{$\begin{array}{l}\text { Arabidopsis } \\
\text { homologue }\end{array}$} & \multirow[b]{2}{*}{ Annotation } & \multicolumn{2}{|c|}{$A Z>$ Prox } & \multicolumn{2}{|l|}{ AZ $>$ Dis } \\
\hline & & & & & $\begin{array}{l}\text { Fold } \\
\text { change } \\
\left(\log _{2}\right)\end{array}$ & $p$-value & $\begin{array}{l}\text { Fold } \\
\text { change } \\
\left(\log _{2}\right)\end{array}$ & $p$-value \\
\hline \multicolumn{9}{|c|}{ Transcription factor } \\
\hline Solyc02g083950 & A_96_P013906 & LeWUS AJ538329 & AT2G17950 & WUS (WUSCHEL) & 8.5 & 0.002 & 8.3 & 0.002 \\
\hline Solyc03g117130 a & A_96_P240288 & SIERF52 AK327476 & AT5G25190 & ethylene-responsive element-binding protein, putative & 7.3 & $<0.001$ & 6.7 & 0.002 \\
\hline Solyc07g066250 & A_96_P000266 & Ls AF098674 & AT1G55580 & LAS (Lateral Suppressor) & 6.0 & 0.008 & 5.9 & 0.008 \\
\hline Solyc11g069030 & A_96_P012746 & Bl AF426174 & AT5G57620 & MYB36 (myb domain protein 36) & 5.5 & 0.008 & 4.5 & 0.007 \\
\hline Solyc07g062840 & A_96_P226779 & GOB FJ435163 & AT5G53950 & ANAC098 | CUC2 (CUP-SHAPED COTYLEDON 2) & 5.2 & 0.002 & 3.8 & 0.003 \\
\hline Solyc09g066360 & A_96_P115892 & SIERF56 TA54084_4081 & AT3G23240 & ERF1 (ETHYLENE RESPONSE FACTOR 1) & 4.9 & 0.014 & 2.3 & 0.019 \\
\hline Solyc01g080960 a & A_96_P017531 & AK330067 & AT4G17800 & DNA-binding protein-related | Predicted AT-hook DNA-binding family protein & 4.7 & 0.014 & 4.1 & 0.009 \\
\hline Solyc08g076010 & A_96_P172039 & BE431711 & AT5G45580 & transcription factor | Homeodomain-like superfamily protein & 3.6 & 0.017 & 3.1 & 0.011 \\
\hline Solyc02g085500 & A_96_P013166 & OVATE AK247861 & AT2G18500 & ATOFP7 (ARABIDOPSIS THALIANA OVATE FAMILY PROTEIN 7) & 2.8 & 0.002 & 1.8 & $<0.001$ \\
\hline Solyc01g102980 & A_96_P226304 & CK715116 & AT1G75240 & AtHB33 (ARABIDOPSIS THALIANA HOMEOBOX PROTEIN 33) & 2.3 & 0.022 & 1.7 & 0.022 \\
\hline Solyc08g065420 & A_96_P014181 & BL4 AF375967 & AT4G32980 & ATH1 (ARABIDOPSIS THALIANA HOMEOBOX GENE 1) & 2.1 & 0.019 & 4.0 & 0.018 \\
\hline Solyc08g078180 & A_96_P030681 & SIERF68 AW034080 & AT5G47220 & ERF2 (ETHYLENE RESPONSIVE ELEMENT BINDING FACTOR 2) & 2.0 & 0.010 & 3.2 & 0.044 \\
\hline Solyc05g005090 & A_96_P012291 & TKn3 U76408 & AT1G23380 & KNAT6 (KNOTTED1-LIKE HOMEOBOX GENE 6) & 1.9 & 0.018 & 4.1 & $<0.001$ \\
\hline \multicolumn{9}{|c|}{ Phytohormone metabolism/signaling/response } \\
\hline Solyc07g063850 & A_96_P127252 & AK319847 & AT5G54510 & GH3.6, DFL1 | DFL1 (DWARF IN LIGHT 1); indole-3-acetic acid amido synthetase & 3.7 & 0.003 & 1.6 & 0.028 \\
\hline Solyc01g109150 & A_96_P011856 & AF461042 & AT5G42650 & AOS (ALLENE OXIDE SYNTHASE) & 3.1 & 0.039 & 3.6 & 0.004 \\
\hline Solyc03g070380a & A_96_P257477 & AK328818 & AT2G23620 & $\begin{array}{l}\text { MES1 (METHYL ESTERASE 1); hydrolase, acting on ester bonds / methyl } \\
\text { indole-3-acetate esterase/ methyl jasmonate esterase/ methyl salicylate esterase }\end{array}$ & 2.5 & $<0.001$ & 1.6 & 0.004 \\
\hline Solyc03g120060 & A_96_P054606 & AB223041 & AT2G26710 & BAS1 (PHYB ACTIVATION TAGGED SUPPRESSOR 1) & 3.1 & 0.011 & 3.2 & 0.015 \\
\hline Solyc02g089160 & A_96_P173339 & Dwarf BE433666 & AT3G30180 & BR6OX2 (BRASSINOSTEROID-6-OXIDASE 2) & 3.3 & 0.024 & 2.8 & 0.048 \\
\hline Solyc12g042500 & A_96_P137617 & Al779761 & AT5G59845 & gibberellin-regulated family protein & 2.0 & 0.020 & 1.7 & 0.002 \\
\hline \multicolumn{9}{|c|}{ Cell wall hydrolysis/modification } \\
\hline Solyc12g096750 & A_96_P012556 & TAPG4 U70481 & AT3G59850 & polygalacturonase, putative / pectinase, putative & 8.7 & 0.016 & 8.6 & 0.022 \\
\hline Solyc12g019180 & A_96_P128437 & NP000616 & AT3G59850 & polygalacturonase, putative / pectinase, putative & 3.0 & 0.005 & 2.1 & 0.017 \\
\hline Solyc01g094970 & A_96_P232064 & AK323960 & AT3G61490 & glycoside hydrolase family 28 protein / polygalacturonase (pectinase) family protein & 4.5 & 0.012 & 4.4 & 0.015 \\
\hline Solyc03g093390 & A_96_P085969 & EXPB2 DQ205653 & AT1G65680 & ATEXPB2 (ARABIDOPSIS THALIANA EXPANSIN B2) & 3.7 & 0.040 & 2.9 & 0.047 \\
\hline Solyc03g006700 & A_96_P077754 & TA38392_4081 & AT5G05340 & peroxidase, putative & 2.6 & $<0.001$ & 4.3 & 0.004 \\
\hline
\end{tabular}


Table 1 Genes up-regulated in the tomato pedicel abscission zone (AZ) compared with the proximal (Prox) and distal (Dis) regions of the pedicel (Continued)

\begin{tabular}{|c|c|c|c|c|c|c|c|c|}
\hline \multicolumn{9}{|l|}{ Defense function } \\
\hline Solyc10g017980 & A_96_P216559 & TA36496_4081 & AT3G12500 & ATHCHIB (ARABIDOPSIS THALIANA BASIC CHITINASE) & 4.2 & 0.004 & 6.7 & $<0.001$ \\
\hline Solyc07g009530 & A_96_P035581 & BW687719 & AT3G12500 & ATHCHIB (ARABIDOPSIS THALIANA BASIC CHITINASE) & 3.5 & 0.014 & 3.3 & 0.034 \\
\hline Solyc10g055800 & A_96_P198339 & Bl209334 & AT3G12500 & ATHCHIB (ARABIDOPSIS THALIANA BASIC CHITINASE) & 1.8 & 0.004 & 2.5 & 0.017 \\
\hline Solyc08g080640 & A_96_P089294 & TA36568_4081 & AT4G11650 & ATOSM34 (osmotin 34) & 5.2 & 0.037 & 2.2 & $<0.001$ \\
\hline Solyc08g080650 & A_96_P156561 & pr p23 AK322366 & AT4G11650 & ATOSM34 (osmotin 34) & 3.6 & 0.048 & 3.3 & 0.011 \\
\hline Solyc01g106620 & A_96_P076884 & AK324158 & AT2G14580 & ATPRB1 (ARABIDOPSIS THALIANA BASIC PATHOGENESIS-RELATED PROTEIN 1) & 5.4 & 0.036 & 6.0 & 0.011 \\
\hline Solyc09g090970 & A_96_P077909 & AK326776 & AT1G24020 & MLP423 (MLP-LIKE PROTEIN 423) & 3.4 & 0.046 & 2.2 & 0.033 \\
\hline Solyc01g097270 & A_96_P148266 & AW037799 & AT3G04720 & PR4 (PATHOGENESIS-RELATED 4) & 2.6 & 0.020 & 1.7 & 0.028 \\
\hline \multicolumn{9}{|l|}{ Lipid metabolism } \\
\hline Solyc01g090350 & A_96_P084944 & BW688588 & AT4G33355 & lipid binding & 2.3 & 0.002 & 1.8 & 0.004 \\
\hline Solyc10g085740 & A_96_P204184 & B1928574 & AT5G03820 & GDSL-motif lipase/hydrolase family protein & 4.2 & 0.041 & 5.3 & 0.035 \\
\hline Solyc12g044950 & A_96_P191076 & cevi19 AK323674 & AT3G12120 & FAD2 (FATTY ACID DESATURASE 2) & 3.5 & 0.046 & 3.3 & 0.042 \\
\hline Solyc02g086490 & A_96_P038006 & GO374663 & AT3G01570 & glycine-rich protein / oleosin & 3.4 & 0.018 & 3.6 & 0.016 \\
\hline Solyc03g083990 & A_96_P077599 & Al777049 & AT2G45180 & protease inhibitor/seed storage/lipid transfer protein (LTP) family protein & 3.2 & 0.010 & 3.7 & 0.029 \\
\hline Solyc09g065240 & A_96_P144011 & AW030712 & AT3G63200 & PLP9 (PATATIN-LIKE PROTEIN 9) & 1.6 & 0.031 & 2.7 & 0.005 \\
\hline \multicolumn{9}{|c|}{ Transporter/Channel } \\
\hline Solyc02g085170 & A_96_P127407 & TA56865_4081 & AT1G19450 & integral membrane protein, putative / sugar transporter family protein & 3.8 & 0.014 & 4.1 & 0.016 \\
\hline Solyc01g103030 & A_96_P114407 & AK325211 & AT1G59740 & proton-dependent oligopeptide transport (POT) family protein & 1.9 & 0.023 & 2.0 & 0.034 \\
\hline Solyc10g084950 & A_96_P231269 & DB697130 & AT2G37900 & proton-dependent oligopeptide transport (POT) family protein & 2.6 & 0.005 & 2.5 & 0.026 \\
\hline Solyc07g063930 & A_96_P137262 & Al778966 & AT3G20660 & AtOCT4 (Arabidopsis thaliana ORGANIC CATION/CARNITINE TRANSPORTER4) & 3.0 & 0.002 & 1.7 & 0.003 \\
\hline Solyc03g005980 & A_96_P190219 & BG134199 & AT4G18910 & $\begin{array}{l}\text { NIP1;2 (NOD26-LIKE INTRINSIC PROTEIN 1;2); arsenite transmembrane } \\
\text { transporter/ water channel }\end{array}$ & 1.8 & 0.006 & 2.4 & 0.016 \\
\hline Solyc01g010080 & A_96_P054371 & AW218955 & AT4G32650 & ATKC1 (ARABIDOPSIS THALIANA K+ RECTIFYING CHANNEL 1) & 3.5 & 0.018 & 2.8 & 0.027 \\
\hline \multicolumn{9}{|l|}{ Others } \\
\hline Solyc12g013820a & A_96_P147601 & AK325708 & AT1G53020 & UBC26 (UBIQUITIN-CONJUGATING ENZYME 26) & 2.2 & $<0.001$ & 2.9 & 0.017 \\
\hline Solyc03g034020 & A_96_P202249 & B1925250 & AT4G36550 & binding / ubiquitin-protein ligase & 2.1 & 0.014 & 1.6 & 0.009 \\
\hline Solyc01g010250 & A_96_P215689 & BP892102 & AT1G13700 & glucosamine/galactosamine-6-phosphate isomerase family protein & 2.1 & 0.006 & 1.7 & 0.002 \\
\hline Solyc12g042470 & A_96_P109252 & TA51045_4081 & AT1G59950 & aldo/keto reductase, putative & 4.2 & 0.018 & 3.8 & 0.045 \\
\hline Solyc00g071180 & A_96_P016051 & AF083253 & AT3G12490 & ATCYSB | cysteine protease inhibitor, putative / cystatin, putative & 1.7 & $<0.001$ & 1.6 & 0.002 \\
\hline Solyc09g089500 & A_96_P141479 & AJ319916 & AT2G38870 & protease inhibitor, putative & 1.8 & 0.044 & 2.7 & 0.035 \\
\hline Solyc01g087820 & A_96_P139602 & AK324419 & AT5G67090 & subtilase family protein & 2.0 & 0.005 & 2.2 & 0.027 \\
\hline
\end{tabular}


Table 1 Genes up-regulated in the tomato pedicel abscission zone (AZ) compared with the proximal (Prox) and distal (Dis) regions of the pedicel (Continued)

\begin{tabular}{|c|c|c|c|c|c|c|c|c|}
\hline Solyc03g112420 & A_96_P203679 & $\mathrm{B} 1927360$ & AT1G64310 & pentatricopeptide (PPR) repeat-containing protein & 2.2 & 0.023 & 1.8 & 0.017 \\
\hline Solyc02g086270 & A_96_P238007 & DB715353 & AT1G67025 & unknown & 1.8 & 0.010 & 1.7 & 0.007 \\
\hline Solyc01g109720 & A_96_P043946 & AK323257 & AT2G18360 & hydrolase, alpha/beta fold family protein & 2.8 & 0.006 & 2.5 & 0.003 \\
\hline Solyc09g008740 & A_96_P160421 & AW625490 & AT2G22880 & VQ motif-containing protein & 2.8 & 0.012 & 2.1 & 0.022 \\
\hline Solyc12g005700 & A_96_P016566 & BT012940 & AT2G32280 & unknown protein & 2.4 & 0.011 & 5.4 & 0.004 \\
\hline Solyc10g007310 & A_96_P084909 & BW687670 & AT2G42610 & LSH10 (LIGHT SENSITIVE HYPOCOTYLS 10) & 2.3 & 0.017 & 3.6 & 0.002 \\
\hline Solyc03g114130 & A_96_P219824 & AK329003 & AT3G01430 & unknown & 1.8 & 0.002 & 1.9 & 0.003 \\
\hline Solyc01g081270 & A_96_P152326 & AK320517 & AT3G09270 & ATGSTU8 (GLUTATHIONE S-TRANSFERASE TAU 8) & 1.6 & 0.011 & 1.6 & 0.041 \\
\hline Solyc08g059710 & A_96_P039956 & AK246959 & AT3G11760 & unknown protein & 2.8 & 0.011 & 2.4 & 0.014 \\
\hline Solyc06g062800 & A_96_P214714 & BP889760 & AT3G13920 & EIF4A1 (EUKARYOTIC TRANSLATION INITIATION FACTOR 4A1) & 2.2 & 0.015 & 2.8 & 0.023 \\
\hline Solyc12g097060 & A_96_P065581 & BI210672 & AT3G23930 & unknown protein & 2.4 & 0.013 & 4.0 & 0.018 \\
\hline Solyc04g074300 & A_96_P191679 & BG626643 & AT3G57490 & 40 S ribosomal protein S2 (RPS2D) & 3.3 & 0.018 & 3.3 & $<0.001$ \\
\hline Solyc08g023270 & A_96_P259047 & TC213163 & AT4G03620 & myosin heavy chain-related & 1.8 & 0.016 & 2.9 & 0.047 \\
\hline Solyc10g054440 & A_96_P089580 & ADC1 AK319876 & AT4G34710 & ADC2 (ARGININE DECARBOXYLASE 2) & 1.9 & $<0.001$ & 2.0 & 0.010 \\
\hline Solyc12g010960 & A_96_P127072 & TA56779_4081 & AT5G16990 & NADP-dependent oxidoreductase, putative & 2.7 & 0.007 & 1.7 & 0.039 \\
\hline Solyc06g082030 & A_96_P226684 & CK720539 & AT5G58660 & oxidoreductase, 2OG-Fe(II) oxygenase family protein & 4.7 & 0.006 & 2.7 & 0.004 \\
\hline Solyc03g114820 & A_96_P112182 & TA53188_4081 & AT5G17390 & universal stress protein (USP) family protein & 2.1 & 0.015 & 1.8 & $<0.001$ \\
\hline Solyc04g050790 & A_96_P170549 & BE344440 & AT5G18310 & unknown protein & 1.9 & 0.005 & 2.9 & 0.003 \\
\hline Solyc01g095960 & A_96_P129692 & Al483484 & AT5G53390 & unknown protein & 3.9 & 0.022 & 1.8 & 0.022 \\
\hline Solyc06g075690 & A_96_P235420 & AK326143 & AT5G59790 & unknown protein & 2.4 & 0.049 & 1.6 & 0.036 \\
\hline Solyc09g055950 & A_96_P108797 & BI211136 & ATCG00270 & PSBD | PSII D2 (PHOTOSYSTEM II REACTION CENTER PROTEIN D2) & 4.1 & 0.019 & 3.9 & 0.038 \\
\hline Solyc09g091400 & A_96_P196349 & BI204004 & AT3G24240 & leucine-rich repeat transmembrane protein kinase, putative & 4.0 & 0.020 & 3.5 & 0.039 \\
\hline Solyc02g084670 & A_96_P112502 & TA53264_4081 & no hits found & & 5.7 & 0.018 & 4.8 & $<0.001$ \\
\hline Solyc01g091400 & A_96_P197999 & Bl208492 & no hits found & & 5.4 & 0.003 & 5.2 & 0.011 \\
\hline Solyc02g031990 & A_96_P224639 & CD002083 & no hits found & & 4.0 & 0.013 & 3.0 & 0.038 \\
\hline Solyc03g070430 & A_96_P106729 & AK247727 & no hits found & & 3.7 & 0.020 & 3.8 & 0.005 \\
\hline ND & A_96_P181929 & BF097523 & no hits found & & 3.3 & 0.007 & 3.3 & 0.001 \\
\hline Solyc03g034360 & A_96_P110867 & TA52360_4081 & no hits found & & 3.0 & 0.043 & 3.1 & 0.031 \\
\hline Solyc08g074680 & A_96_P207909 & BM410550 & no hits found & & 2.8 & 0.005 & 2.9 & 0.012 \\
\hline Solyc04g055050 & A_96_P062011 & AW222670 & no hits found & & 2.8 & 0.001 & 1.9 & 0.001 \\
\hline ND & A_96_P261677 & TC215751 & no hits found & & 2.3 & 0.022 & 2.2 & 0.033 \\
\hline
\end{tabular}


Table 1 Genes up-regulated in the tomato pedicel abscission zone (AZ) compared with the proximal (Prox) and distal (Dis) regions of the pedicel (Continued)

\begin{tabular}{|c|c|c|c|c|c|c|c|}
\hline ND & A_96_P246260 & AK325898 & no hits found & 2.1 & 0.028 & 1.6 & 0.012 \\
\hline ND & A_96_P104119 & AK325900 & no hits found & 2.0 & 0.016 & 1.9 & 0.021 \\
\hline ND & A_96_P204674 & B|929508 & no hits found & 2.0 & 0.047 & 3.5 & 0.030 \\
\hline Solyc07g056280 & A_96_P131347 & Al487047 & no hits found & 1.8 & 0.008 & 2.1 & 0.015 \\
\hline ND & A_96_P069949 & DB717716 & no hits found & 1.6 & 0.026 & 3.6 & 0.025 \\
\hline Solyc03g113910 & A_96_P201699 & B1924325 & no hits found & 1.6 & 0.049 & 3.6 & 0.026 \\
\hline ND & A_96_P160681 & AW626075 & no hits found & 1.6 & 0.013 & 2.0 & 0.011 \\
\hline
\end{tabular}

If more than two probes derived from the same gene were selected, only the result of the probe indicating the highest fold change value was shown in this table. Each assay result is shown in Additional file 1 and 2. Genes examined by RT-PCR are marked with lower case "a". 
As a result, we found that 426 probes showed higher signal intensity in the AZ than in Prox, and 319 probes were higher in the AZ than in Dis (Additional file 1 and 2). In total, 112 probes showed higher signal intensity in the AZ than in both Prox and Dis (Figure 1B). Of the EST sequences for the 112 probes, 105 ESTs represented 82 International Tomato Annotation Group (ITAG2)-predicted genes, but the remaining 7 ESTs have not yet been assigned to any predicted genes (Table 1). Here we regarded the 82 predicted genes and 7 nonassigned ESTs as independent genes, and further examined the functions of these 89 genes. To verify the microarray assay results, we arbitrarily selected 10 genes out of the 89 genes and analyzed expression of the 10 genes by reverse transcription PCR (RT-PCR) (Additional file 3). The expression specificities within the three pedicel regions showed good consistency between the RT-PCR and the microarray results.

Based on the annotation of their Arabidopsis homologues, we inferred the function of the 89 genes preferentially expressed in the AZ. From the putative functions of these 89 genes, we found 6 major functional groups: transcription factors (13 genes), phytohormone metabolism, signaling and response (6 genes), cell walldegrading or modification (5 genes), defense function (8 genes), lipid metabolism (6 genes) and transporter/ channel proteins (6 genes) (Table 1$)$.

We also identified genes for which expression in the AZ was lower than that in Prox and Dis. The genes showing AZ expression levels of less than one-third of that detected in both Prox and Dis $(\mathrm{p}<0.05)$ were selected. This group included only four ESTs, BF114405, TA41413_4081, AK248036, and AK324977 (Additional file 4). AK324977 encodes a homologue of a putative auxin-responsive protein, whereas the others showed no sequence similarity to any known genes. The result was insufficient to assess specific features of the AZ cells thus we did not analyze these four further.

\section{Transcription factor genes specifically up-regulated in the $A Z$}

We previously reported that pedicel AZ cells at anthesis express the transcription factor genes $B l, G O B, L s$ and LeWUS, which have been identified as regulators of apical or axillary meristem development. In addition to these 4 genes, here we found 9 other transcription factor genes that were preferentially expressed in pedicel AZs at anthesis (Table 1). The 9 identified genes belong to 7 transcription factor families: a KNOX family gene (Tomato Knotted 3 [TKn3]), a BELL family gene (belllike homeodomain protein 4 [BL4]), a zinc fingerhomeodomain (ZF-HD) family gene (CK715116), an OVATE family gene (OVATE), 3 ethylene responsive transcription factor (ERF) family genes (SIERF52,
SlERF56 and SlERF68), an AT-hook family gene (AK330067) and a homeodomain-like superfamily gene (BE431711) (Table 1). OVATE, SIERF52 and CK715116 are expressed in an $M C$ and JOINTLESS dependent manner in tomato pedicels, similar to $B l, G O B, L s$ and LeWUS [10]. Previous studies showed that several transcription factor families described here play roles in organ abscission. For example, the KNOX family transcription factors, which were first identified to regulate shoot meristem identity [35], were also shown to be involved in abscission processes in floral organs [36,37]. Also, the BELL family gene $q S H 1$ regulates formation of the abscission zone in rice seed shattering [19]. Some of the transcription factor families found in AZs are involved in phytohormone metabolism and signaling pathways. For example, the CK715116 encoding protein showed sequence similarity to the Arabidopsis ZF-HD family gene $H O M E O B O X P R O T E I N 33$, which functions in the abscisic acid (ABA) response pathway [38]. The AT-hook family controls inflorescence formation, senescence, and gibberellin (GA) metabolism [39-41]. Members of the ERF family were originally identified as regulators of ethylene signaling but are now known to respond to abiotic and biotic stresses and regulate lipid metabolism and development [42-45]. The OVATE family proteins have been identified as regulators of cell elongation, and tomato OVATE regulates fruit shape $[46,47]$.

\section{Phytohormone related genes specifically up-regulated in the $A Z$}

Because pedicel abscission at the pre-abscission stage is prevented by auxin, we expected that genes related to auxin activities would be expressed predominantly in the AZ. Indeed, AK328818 and AK319847, which are homologues of METHYLESTERASE1 (MES1) and DWARF IN LIGHT1 (DFL1)/ auxin-inducible Gretchen Hagen 3.6 (GH3.6), respectively, showed higher transcript levels in the AZ than in Prox and Dis (Table 1). MES1 is implicated in conversion of a storage form of indole-3-acetic acid (IAA) into the active form and DFL1 encodes an IAA amido synthetase, which produces a storage form of IAA from the active form [48-50]. In addition, several genes involved in pathways related to diverse phytohormones showed higher expression in the AZ than in nonAZ tissues; these include genes involved in jasmonate (JA) metabolism (AF461042), brassinosteroid metabolism and biosynthesis (Dwarf and AB223041) and GA signaling regulation (AI779761).

\section{Cell wall degrading and remodeling genes specifically up-regulated in the $A Z$}

Our transcriptome analyses showed that several genes for cell wall degrading and remodeling factors were 


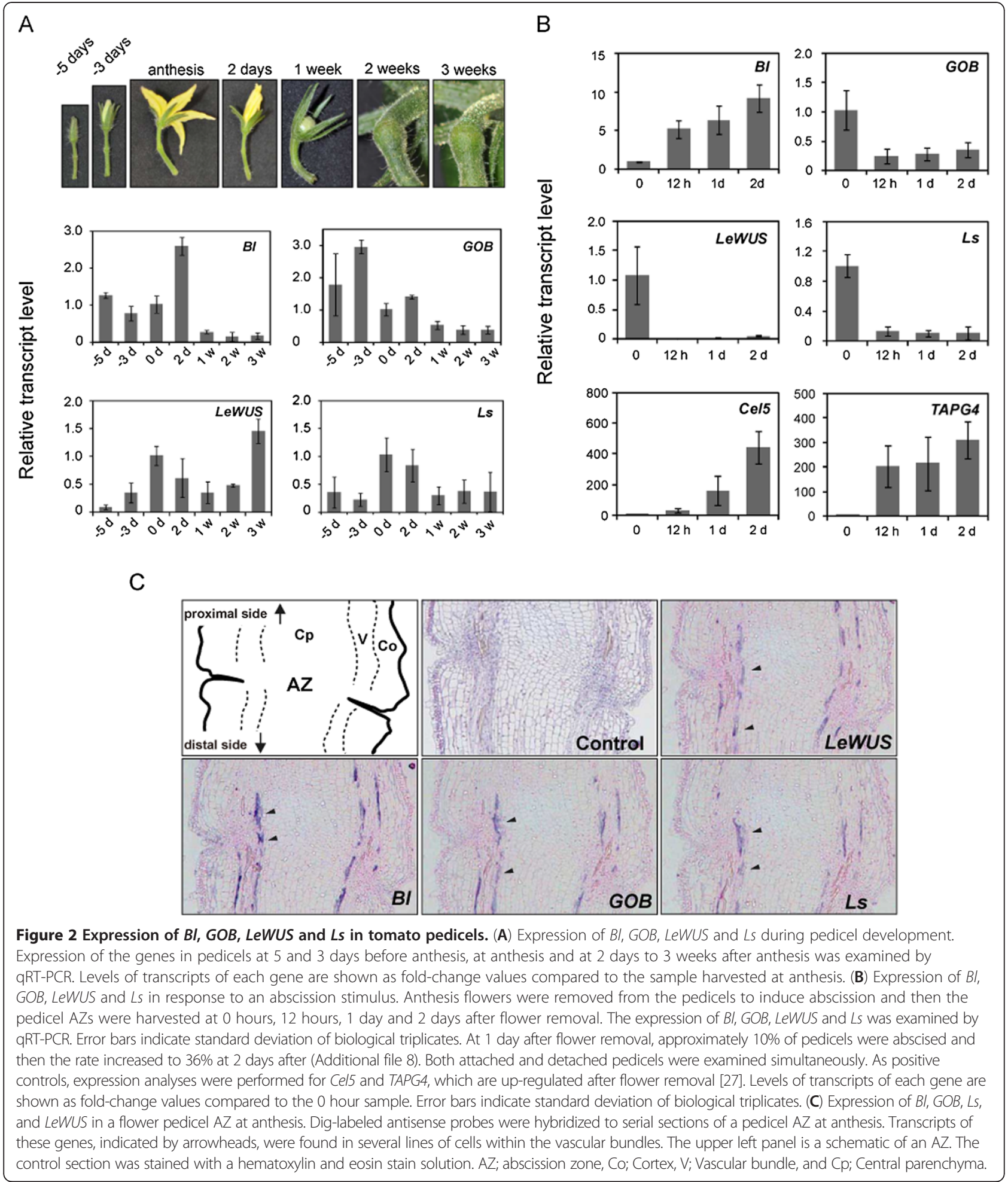

expressed at higher levels in the AZ than in the non-AZ tissues. These include genes for polygalacturonase (PG), peroxidase and expansin. PG, an enzyme that hydrolyzes cell wall pectin, has been demonstrated to promote abscission in various plant organs [51,52] and PG genes are strongly up-regulated at the onset of abscission in tomato pedicels [27] and citrus (Citrus clementina) leaves [29]. In tomato pedicels, PG expression is strictly limited to the AZ after initiation of abscission [53]. Expansin is a cell wall remodeling protein and reportedly 
Table 2 Genes preferentially expressed in a tomato pedicel proximal region (Prox) compared with the distal region (Dis)

\begin{tabular}{|c|c|c|c|c|c|c|c|c|}
\hline \multirow[b]{2}{*}{$\begin{array}{l}\text { Tomato gene } \\
\text { ID }\end{array}$} & \multirow[b]{2}{*}{ Probe ID } & \multirow[b]{2}{*}{$\begin{array}{l}\text { Gene name / EST accession } \\
\text { number }\end{array}$} & \multirow[b]{2}{*}{$\begin{array}{l}\text { Arabidopsis } \\
\text { homologue }\end{array}$} & \multirow[b]{2}{*}{ Annotation } & \multicolumn{2}{|l|}{ Prox $>$ Dis } & \multicolumn{2}{|l|}{ Prox $>A Z$} \\
\hline & & & & & $\begin{array}{l}\text { Fold change } \\
\left(\log _{2}\right)\end{array}$ & $\begin{array}{l}p- \\
\text { value }\end{array}$ & $\begin{array}{l}\text { Fold change } \\
\left(\log _{2}\right)\end{array}$ & $\begin{array}{l}p \text { - } \\
\text { value }\end{array}$ \\
\hline \multicolumn{9}{|c|}{ Transcription factor } \\
\hline Solyc12g009580 & A_96_P138787 & Al782101 & AT2G26580 & YAB5 (YABBY5) & 5.0 & 0.015 & 3.2 & 0.074 \\
\hline Solyc01g096070 & A_96_P108377 & TA50096_4081 & AT4G23980 & ARF9 (AUXIN RESPONSE FACTOR 9) & 3.4 & 0.005 & 0.3 & 0.059 \\
\hline Solyc08g076820 & A_96_P101994 & AK323669 & AT5G46690 & bHLH071 (basic-helix-loop-helixHLH protein 71) & 3.4 & 0.002 & 1.5 & 0.003 \\
\hline Solyc06g005310 & A_96_P124087 & TA56053_4081 & AT3G46130 & MYB111 (MYB DOMAIN PROTEIN 111) & 3.6 & 0.036 & 2.5 & 0.007 \\
\hline Solyc12g056460 & A_96_P182539 & SIMBP14 BF098196 & AT2G45660 & SOC1 | AGL20 (AGAMOUS-LIKE 20) & 3.7 & 0.018 & 2.0 & 0.069 \\
\hline Solyc06g065820a & A_96_P012741 & SIERF1 AY077626 & AT5G25190 & $\begin{array}{l}\text { ethylene-responsive element-binding protein, } \\
\text { putative }\end{array}$ & 3.7 & 0.006 & 1.4 & 0.007 \\
\hline \multicolumn{9}{|c|}{ Phytohormone-related function } \\
\hline Solyc08g014000 & A_96_P012631 & LOXA U09026 & AT1G55020 & LOX1 & 3.6 & 0.008 & -0.8 & 0.365 \\
\hline Solyc11g011210 & A_96_P190874 & RSI-1 AK324086 & AT3G02885 & GASA5 (GAST1 PROTEIN HOMOLOG 5) & 4.2 & 0.019 & -0.7 & 0.014 \\
\hline
\end{tabular}

If more than two probes derived from the same gene were selected, only the result of the probe indicating the highest fold change value was shown in this table. Each assay result is shown in Additional file 5. Genes examined by RT-PCR are marked with lower case "a". 
Table 3 Genes up-regulated in the tomato pedicel distal region (Dis) compared with the proximal region (Prox)

\begin{tabular}{|c|c|c|c|c|c|c|c|c|}
\hline \multirow[b]{2}{*}{ Tomato gene ID } & \multirow[b]{2}{*}{ Probe ID } & \multirow[b]{2}{*}{$\begin{array}{l}\text { Gene name / EST } \\
\text { accession number }\end{array}$} & \multirow[b]{2}{*}{$\begin{array}{l}\text { Arabidopsis } \\
\text { homologue }\end{array}$} & \multirow[b]{2}{*}{ Annotation } & \multicolumn{2}{|l|}{ Dis $>$ Prox } & \multicolumn{2}{|l|}{ Dis $>A Z$} \\
\hline & & & & & Fold change $\left(\log _{2}\right)$ & $p$-value & Fold change $\left(\log _{2}\right)$ & $p$-value \\
\hline \multicolumn{9}{|c|}{ Transcription factor } \\
\hline Solyc02g089200ª & A_96_P195359 & TM29 BG734619 & AT5G15800 & SEP1 (SEPALLATA1) & 8.8 & 0.004 & 2.4 & $<0.001$ \\
\hline Solyc05g015750 & A_96_P000181 & TDR5 AY294330 & AT1G24260 & SEP3 (SEPALLATA3) & 7.4 & 0.018 & 4.6 & $<0.001$ \\
\hline Solyc07g006880 & A_96_P040576 & AK326074 & AT5G57520 & ZFP2 (ZINC FINGER PROTEIN 2) & 7.0 & 0.006 & 3.0 & $<0.001$ \\
\hline Solyc01g093960a & A_96_P204169 & Bl203609 & AT2G45650 & AGL6 (AGAMOUS-LIKE 6) & 6.5 & 0.005 & 0.4 & 0.041 \\
\hline Solyc06g073920 & A_96_P249912 & AK328263 & AT1G08465 & YAB2 (YABBY2) & 5.6 & $<0.001$ & 1.2 & 0.013 \\
\hline Solyc02g085630 & A_96_P039876 & Al898032 & AT4G36740 & ATHB40 (ARABIDOPSIS THALIANA HOMEOBOX PROTEIN 40) & 5.5 & 0.023 & 0.6 & 0.059 \\
\hline Solyc02g086690 & A_96_P163816 & AW737355 & AT5G40350 & MYB24 (myb domain protein 24) & 5.1 & $<0.001$ & 1.5 & 0.009 \\
\hline Solyc12g038510 & A_96_P114197 & SIMBP21 TA53678_4081 & AT5G15800 & SEP1 (SEPALLATA1) & 5.0 & 0.001 & 0.2 & 0.051 \\
\hline Solyc12g100150 & A_96_P191189 & AK328730 & AT1G31320 & LBD4 (LOB DOMAIN-CONTAINING PROTEIN 4) & 4.8 & 0.001 & 1.1 & 0.028 \\
\hline Solyc01g106250 & A_96_P113847 & TA53587_4081 & AT5G60142 & DNA binding & 4.6 & 0.010 & 1.2 & 0.024 \\
\hline Solyc02g085910 & A_96_P050501 & AK328874 & AT3G02550 & LBD41 (LOB DOMAIN-CONTAINING PROTEIN 41) & 4.3 & 0.006 & 0.8 & 0.127 \\
\hline Solyc04g079360 & A_96_P185909 & BG126724 & AT3G50060 & MYB77 (myb domain protein 77) & 4.2 & 0.008 & 1.8 & 0.005 \\
\hline Solyc04g081000a & A_96_P206659 & TAP3 DQ674532 & AT3G54340 & AP3 (APETALA 3) & 4.1 & 0.004 & 1.2 & 0.017 \\
\hline Solyc07g008020 & A_96_P212749 & AK319758 & AT4G32280 & IAA29 (INDOLE-3-ACETIC ACID INDUCIBLE 29) & 4.0 & 0.005 & 1.8 & 0.076 \\
\hline Solyc03g044300 & A_96_P172149 & SIAP2a AK326004 & AT4G36920 & AP2 (APETALA 2) & 3.8 & 0.007 & 2.0 & 0.022 \\
\hline Solyc07g066330 & A_96_P252807 & TC202847 & AT1G56010 & ANAC022 | NAC1 & 3.4 & 0.012 & 0.1 & 0.494 \\
\hline Solyc07g063410 & A_96_P046081 & AK323372 & AT4G27410 & ANAC072 | RD26 (RESPONSIVE TO DESICCATION 26) & 3.3 & 0.018 & 0.9 & 0.101 \\
\hline \multicolumn{9}{|c|}{ Phytohormone-related function } \\
\hline Solyc02g064690a & A_96_P209009 & BP875651 & AT4G37580 & HLS1 (HOOKLESS 1) & 4.8 & 0.003 & 2.4 & 0.001 \\
\hline Solyc02g092490 & A_96_P079464 & AK247718 & AT4G37580 & HLS1 (HOOKLESS 1) & 3.6 & 0.019 & 1.2 & 0.101 \\
\hline Solyc01g107400 & A_96_P042196 & BW692346 & AT2G14960 & $\mathrm{GH} 3.1$ & 4.0 & 0.035 & 1.7 & 0.008 \\
\hline Solyc07g026650 & A_96_P020931 & SIACO5 AJ715790 & AT2G19590 & ACO1 (ACC OXIDASE 1) & 4.4 & 0.020 & 0.2 & 0.553 \\
\hline Solyc10g017990 & A_96_P028296 & BG130984 & AT5G56970 & CKX3 (CYTOKININ OXIDASE 3) & 4.3 & 0.026 & -1.5 & 0.291 \\
\hline Solyc12g008900 & A_96_P107909 & TA49618_4081 & AT5G56970 & CKX3 (CYTOKININ OXIDASE 3) & 4.3 & 0.017 & -1.5 & 0.296 \\
\hline
\end{tabular}

If more than two probes derived from the same gene were selected, only the result of the probe indicating the highest fold change value was shown in this table. Each assay result is shown in Additional file 6. Genes examined by RT-PCR are marked with lower case "a". 
regulates abscission of leaflets in elderberry (Sambucus nigra) and pedicels in Arabidopsis [25,26]. Gene expression or enzyme activity of peroxidases is detected during abscission in tobacco (Nicotiana tabacum) flower pedicels and citrus leaves $[29,54]$. Although the expression of the genes for PG, expansin and peroxidase were expressed preferentially in AZs, the expression levels of the genes at the pre-abscission stage was much lower than after the onset of abscission (Figure 2B) [25,27]. Thus, these proteins may have different functions between pre-abscission and during abscission. During the pre-abscission stage, these genes may be involved in AZ tissue maintenance or thickening of the AZ by remodeling cell wall components. It is also possible that the PG activity at anthesis may be too low to have any significant effect on cells, because the expression level was much lower than that during the abscission activated stage (Figure 2B).

\section{Defense-related and lipid metabolism genes specifically up-regulated in the $A Z$}

Several pathogenesis-related $(P R)$ genes are reportedly expressed at the site where organs will be shed during abscission [1]. The $P R$ genes are expected to function in defense to prevent potential pathogen infections during abscission [1]. Many $P R$ genes are also expressed in unstressed tissues such as poplar leaves and tobacco flowers, possibly for development or basal defense activity against opportunistic pathogen invasion [55,56]. Our transcriptome analysis also revealed that homologues of defenserelated genes encoding basic chitinases (TA36496_4081, BW687719 and BI209334), PR4 (AW037799), basic PR1 (AK324158), osmotin proteins (TA36568_4081 and pr p23) and a major latex protein-like protein (AK326776) were preferentially expressed in AZs at anthesis.

Lipids may act as an additional defense against pathogen infection or dehydration at abscission. An anatomical study revealed that the clefts in pedicel AZs are filled with lipid compounds such as cutin [57] and our previous study showed that many lipid metabolism genes were down-regulated in the pedicels of non-AZ-forming plants (antisense- $M C$ transgenic plants and jointless mutants) compared with wild-type plants [10]. Accordingly, we found that 6 homologues associated with lipid metabolism were preferentially expressed in the AZ; the genes encode a lipid binding protein (BW688588), a GDSL-motif lipase/hydrolase (BI928574), a fatty acid desaturase (citrus exocortis viroid-inducible19 [cevi19]), a protease inhibitor/seed storage/lipid transfer protein (AI777049), a glycine rich protein/oleosin (GO374663), and a patatin-like protein (AW030712) (Table 1).

\section{Genes differentially expressed between Prox and Dis}

Previous investigations showed that, after the onset of abscission, the Prox and Dis tissues show distinct expression patterns for several abscission-related genes such as PG, $\beta-1,4-$ glucanase (cellulose) and ribonuclease at anthesis $[51,58,59]$. In this study, we analyzed expression pattern differences between the two tissues at the anthesis stage, or pre-abscission stage. By using foldchange $>3(p<0.05)$ as a cutoff, we found that 629 probes showed higher signal intensity in Prox than in Dis (Figure 1C, Additional file 5) and 392 probes were higher in Dis than in Prox (Figure 1C, Additional file 6). Subsequently, among these genes, we focused on transcription factors and phytohormone-related genes. By using more strict criteria, fold-change $>10(p<0.05)$, as a cutoff, we identified 6 transcription factor genes and 2 phytohormone-related genes that were preferentially expressed in Prox (Table 2), and 17 transcription factor genes and 6 phytohormone-related genes that were preferentially expressed in Dis (Table 3). We also used RTPCR to verify the results of the microarray analyses for 11 arbitrarily selected genes and found that the RT-PCR results were consistent with the microarray data (Additional file 7).

\section{Transcription factor genes differentially expressed between Prox and Dis}

Among the genes preferentially expressed in Dis, we found five MADS-box genes (BI203609, MADS-box 5 [TDR5 or TM5], TM29, MADS-box Protein 21 [SlMBP21], and Tomato APETALA3 [TAP3]), which are homologous to AGAMOUS-LIKE6 (AGL6), SEPALATA1 (SEP1), SEPALATA3 (SEP3) or AP3, the Arabidopsis regulators of flower organ identity (Table 3). An APETALA2 (AP2) homologue (SlAP2a) was also found among the genes preferentially expressed in Dis. Arabidopsis AP2 encodes a transcription factor belonging to the AP2 family and regulates flower organ identity [60]; the tomato homologue SIAP2a has been shown to be a negative regulator of ethylene biosynthesis during fruit ripening [61]. Recently, a rice $A P 2$ homologue has been shown to regulate $\mathrm{AZ}$ development for seed shattering [18]. By contrast, among the transcription factor genes preferentially expressed in Prox, we found a homologue of Arabidopsis SUPPRESSOR OF OVEREXPRESSION OF CONSTANS 1 (SOC1), which encodes a MADS-box protein regulating floral meristem identity (SIMBP14; Table 2) [62,63].

Several transcription factor genes implicated in auxinregulated signaling pathways showed differential expression between Prox and Dis. For example, an auxin response factor (ARF) family gene (TA50096_4081) was preferentially expressed in Prox. The genes preferentially expressed in Dis include homologues that encode members of the auxin/indole-3-acetic acid (AUX/IAA) family (AK319758), NAC family (TC202847), and MYB family (BG126724). ARF family proteins are implicated as regulators of auxin signaling [64] and Arabidopsis ARF1, and 
$A R F 2$ are redundantly required to promote floral organ abscission [65]. AK319758 encodes a homologue of Arabidopsis IAA29, which is involved in auxin-mediated elongation of hypocotyls [66]. BG126724 is a MYB77 homologue that modulates auxin signaling [67]. TC202 847 shows similarity to $N A C 1$, which is involved in auxin-mediated lateral root formation [68].

A $Y A B$ family gene (AI782101) was preferentially expressed in Prox and another $Y A B$ homologue (AK328263) was preferentially expressed in Dis. YAB family proteins act as regulators to establish abaxial cell fates during lateral organ development in Arabidopsis [69]. Recently, a $Y A B$ homologue gene $S H 1$ and its homologue genes were identified to regulate seed shattering in cereal species, including sorghum, rice and maize [20].

\section{Phytohormone-related genes with distinct expression patterns between Prox and Dis}

The genes expressed at higher levels in Dis than in Prox included several homologues of genes regulating phytohormone activities (Table 3). For example, BW692346 encodes a homologue of GH3.1, which mediates auxin conjugation [48]; BP875651 and AK247718 encodes homologues of HOOKLESS1 (HLS1), which serves as an integrator of ethylene, auxin, and light signaling pathways in differential cell elongation in Arabidopsis hypocotyls [70]. SlACO5 encodes a 1-amino-cyclopropane-1carboxylic acid oxidase (ACO), which catalyzes ethylene biosynthesis and BG130984 and TA49618_4081 are homologues of CYTOKININ OXIDASE3, which encodes a cytokinin oxidase that degrades cytokinins. We also found two phytohormone-related genes that are expressed preferentially in Prox, LIPOXYGENASE A (LOXA) and Root System Inducible1 (RSI-1) (Table 2). $L O X A$ encodes a lipoxygenase of the 9-LOX pathway and is proposed to function in biosynthesis of oxylipins [71]. Products of the 9-LOX pathway share similar biological functions with JAs in defense responses [72,73]. RSI-1 is a member of the GASA (for GA-stimulated Arabidopsis) gene family, which includes regulators involved in cell and organ elongation [74]; RSI-1 has been identified as a regulator of lateral root development [75]

\section{Spatiotemporal expression of $B l, G O B$, Ls and LeWUS in response to an abscission signal}

We previously showed that $B l, G O B, L s$ and LeWUS are preferentially expressed in anthesis pedicel AZs under the regulation of $M C$ and JOINTLESS. Here we carried out a more detailed analysis of their expression patterns. First, we analyzed their expression during pedicel development from 5 days before anthesis to 3 weeks after anthesis by quantitative RT-PCR (Figure 2A). A substantial amount of $B l$ expression was detected from 5 days before anthesis and the expression reached its maximal level at 2 days after anthesis, while the level was markedly decreased during the fruit growing stage. The highest expression of $G O B$ was detected at 3 days before anthesis and then the expression level gradually decreased. Expression of LeWUS and Ls reached their peak at anthesis and then decreased gradually, similar to that of $G O B$. Unlike the other three genes, expression of LeWUS increased again during the fruit growing stage and its highest expression was detected at 3 weeks after anthesis. Next, we examined the effects of a flower abscission signal on the transcript levels of the four genes (Figure 2B). Abscission of the pedicel AZ is stimulated by removing the flower from the pedicel. Following this treatment, $10 \%$ and $36 \%$ of pedicels were abscised after one and two days, respectively (Additional file 8). After removing flowers, the expression of $G O B, L s$ and LeWUS at the pedicel immediately declined within 12 hours, but $B l$ expression increased more than 5-fold after the treatment. Subsequently, to identify the cells transcribing the 4 transcription factor genes, AZ regions at anthesis were examined by in situ hybridization. Serial sections of the AZ regions were prepared and hybridized with the antisense probes for $B l, G O B, L s$ and LeWUS. As shown in Figure 2C, mRNAs of $B l, G O B, L s$ and LeWUS were detected in the same cells; these cells were arranged as several lines within the vascular tissue between the cortex and central parenchyma. When the hybridizations were conducted with sense probes as negative controls, we detected no specific hybridization signals (Additional file 9). The patterns of $B l, G O B, L s$ and LeWUS were similar to that of TAPG4 (Additional file 9), whose expression is reportedly detected around the vascular cells within the $\mathrm{AZ}$ tissue of the tomato pedicel [53].

\section{Discussion}

Several pathways in anthesis pedicel AZs may be shared with the regulation of shoot apical meristems (SAMs)

Our analyses of gene expression in anthesis pedicels revealed distinct expression patterns in the AZ compared to other pedicel tissues, Prox and Dis regions. We previously showed that the transcription factors regulating shoot meristem maintenance and lateral shoot development, LeWUS, $B l, G O B$ and $L s$, are expressed in anthesis pedicel AZs [10]. In addition to these four genes, here we identified several homologues of transcription factor genes that were identified to regulate meristem activities. Tkn3 and BL4, both of which were up-regulated in AZ, encode homologues of Arabidopsis KNOX and BELL family transcription factors, respectively, which form a heterodimer required for SAM function [76]. Moreover, our analyses also revealed AZ specific up-regulation of OVATE, the homologue of which binds to the KNOX-BELL heterodimer complex 
and modulates activity of the complex [77]. In addition, another transcription pathway found in the SAM may also be activated in anthesis pedicels. Arabidopsis $Y A B$ genes, which are expressed in abaxial domains of leaves, promote stem cell activity in the meristem through the activity of LATERAL SUPPRESSOR (LAS), which is expressed at the boundary of the leaf organ primordium and SAM central zone [78,79]. Our analyses found that the LAS homologue Ls was expressed in the AZ and the $Y A B$ homologues were expressed outside of the $\mathrm{AZ}$, in the Prox and Dis regions (Table 1, Table 2 and Table 3), suggesting the similarity of the spatial expression patterns of the $L A S$ and $Y A B$ family genes between pedicels and shoot apices. This evidence supports our proposal that transcriptional regulation occurring in $\mathrm{AZs}$ is shared with the regulation found in SAMs. If so, how does this common regulation act on these dissimilar tissues and what cell activities does it regulate? Observations of pedicel AZs showed that small cells with densely packed cytoplasm are arranged within AZs $[34,80]$ and these cells are assumed to be maintained in an undifferentiated state [3]. Therefore, one plausible explanation is that the common regulatory system in pedicel AZs and SAMs may serve to maintain small, undifferentiated cells in both tissues. This hypothesis is supported by the fact that WUS and KNOX, with homologues that were up-regulated in pedicel AZs, are the key genes regulating maintenance of undifferentiated meristem cells [81-83]. Moreover, a recent investigation showed that KNOX family genes determine the timing of floral organ abscission via regulation of the size and proliferation of the AZ cells [36]. In addition, pedicel AZs can develop adventitious shoots, although the event is rare [10], also supporting the possibility that pedicel AZs contain cells with features similar to SAM cells.

\section{Involvement of LeWUS, BI, GOB and $L s$ in regulation of competency to respond to abscission-promoting signaling}

Here we analyzed expression specificities of LeWUS, Bl, $G O B$ and $L s$ in pedicels to unveil the functions of these AZ-specific genes in abscission. Expression patterns of these 4 genes were remarkably altered by an abscissioninitiating stimulus; transcript levels of LeWUS, GOB and $L s$ declined significantly and $B l$ was substantially upregulated (Figure $2 \mathrm{~B}$ ). The alternations were significantly different from the expression pattern changes that occur in normal tissue development (Figure 2A). Thus, these four transcription factor genes are likely to be involved in the regulation of the onset of abscission. The expression patterns suggest that $B l$ may be a positive regulator of abscission whereas other three may be negative regulators. During normal tissue development, the expression peaks of these four genes occurred within a few days before and after anthesis (Figure 2A). The developmental stage appears to be critical to determine whether the organ is abscised or transited to the growth phase. Therefore, the tissue may require high level expression of positive and negative regulators to respond immediately to either of the fates. If the tissue is to be abscised, the positive regulators would be up-regulated and the negative ones down-regulated. Alternatively, if the tissue is to transit to the growth phase, the high level expression of both regulators may not be required, probably because abscission is suppressed by the stable supply of the abscission inhibitor auxin from the fruit.

The difference in responses between $B l$ and the other 3 genes was unexpected because the AZ specific expression of all these genes is simultaneously regulated by $\mathrm{MC}$ and JOINTLESS [10], and a previous study proposed that REGULATOR OF AXILLARY MERISTEM (RAX), CUP-SHAPED COTYLEDON (CUC) and LAS, which are Arabidopsis homologues of $B l, G O B$ and $L s$, are positive regulators that compose a transcription cascade in the axillary meristem [84]. A converse hypothesis, that $R A X$ and $L A S$ are elements of two independent transcription pathways, was also proposed [85]. The expression of $B l$, LeWUS, GOB and $L s$ in AZ may be regulated by dual mechanisms, in which a common regulatory factor may induce these four genes before the onset of anthesis, and once an abscission signal is provided, different transcriptional regulators may upregulate $B l$ or down-regulate the other three genes.

The expression properties of LeWUS and GOB indicate a probable explanation for the physiological changes in pedicel AZ cells during abscission. Histological analysis of the tomato pedicel AZ revealed that the separation zone cells that remain small before abscission do enlarge just after the onset of abscission [86]. It has been proposed that the enlargement of AZ cells at the onset of abscission produces a force that ruptures the separation zone [36,87]. As described above, WUS functions to maintain cells in an undifferentiated state in SAMs; $C U C$, a homologue of $G O B$, also acts to keep cell size small $[83,88]$. Therefore, the reduced expression of $G O B$ and LeWUS caused by an abscission signal may result in the enlargement of the separation zone cells for the onset of abscission. Of the four genes, only LeWUS showed increased expression at 3 weeks after anthesis. Because the separation zone cells increase until the mature green fruit stage [80], increasing activity of LeWUS may be required to maintain the physiology of the cells.

As shown in Figure 2C, LeWUS, Bl, GOB and $L s$ were all expressed in the vascular cells of the pedicel, but not in the small cells at the separation zone. In SAMs, WUS regulates stem cell activity and is expressed in cells underneath the stem cells, but not in the stem cells themselves [83]. RAX,CUC and $L A S$, the homologues of 
$B l, G O B$ and $L s$, respectively, are expressed in a boundary region between the SAM and leaf primordium $[84,85,89]$. If separation zone cells in the pedicel AZs possess similar properties with SAMs as described above, the expression of LeWUS, Bl, GOB and Ls outside of the separation zone cells is consistent with the observation in SAMs. These four genes may regulate activities of the separation zone cells in AZs through non-cell autonomous mechanisms similar to the regulation of SAM activity by WUS or LAS [78,90]. Although the functions of these 4 genes in pedicel AZs is still unclear, our expression analyses suggest that these four genes make significant contributions to the response to the onset of the abscission. Further investigation will provide key insights into the functions of these transcription factors in the regulation of abscission.

\section{An auxin gradient may be formed in the pedicel and affect gene expression}

Several lines of evidence indicate that auxin and ethylene are critical factors that regulate the onset of abscission, and auxin plays a role in maintenance of flower or fruit attachment to the plants $[1,22]$. Our results revealed that expression patterns of genes that are involved in auxin signaling and auxin homeostasis were obviously different in the three pedicel regions, AZ, Prox and Dis. Homologues of the genes for IAA amide synthases DFL1/ GH3.6 (AK319847) and GH3.1 (BW692346) were preferentially expressed in AZ and Dis, respectively, but no homologue was found in the genes preferentially expressed in the Prox region. IAA amide synthase genes are induced in auxin-abundant tissues and the gene products inactivate IAA to control auxin homeostasis [91], suggesting that the auxin concentrations in the Dis and $A Z$ regions at anthesis are higher than that in the Prox region. Meanwhile, genes preferentially expressed in the AZ included a homologue of the gene for MES1 (AK328818), which can convert an inactive form of IAA, IAA-methyl ester (MeIAA), into the active form, IAA [49]. These results suggest that the level of active IAA in $\mathrm{AZ}$ at anthesis may be fine-tuned in a complex manner. These opposite reactions, namely activation and inactivation of IAA, may occur in different cell-groups within the AZ to maintain its pre-abscission status. We also found a homologue of $I A A 29$, an auxin-inducible transcription factor gene [66], in the genes preferentially expressed in the Dis region (AK319758; Table 3). The expression of the IAA29 homologue was the highest in the Dis region and gradually decreased toward Prox (Additional file 10). In addition, several genes that may play roles in auxin signaling, such as homologues of MYB77 (BG126724) and NAC1 (TC202847), had more abundant transcripts in Dis than in Prox (Table 3). These results also support the possibility that an auxin gradient is formed in the pedicel tissues. In contrast, the transcript level of the auxin response factor ARF9 homologue was significantly higher in Prox (Table 2 and Additional file 10). Generally, transcription factor activities of ARFs are modulated by post-transcriptional regulation; ARF activity is inhibited by conjugation of AUX/ IAA proteins and the ARFs are activated when the auxin level in the cell is elevated and the increased auxin induces degradation of the conjugated AUX/IAAs [92]. Although it is unknown whether the transcript level of the ARF9 homologue in Prox is regulated by auxin concentration, the high level expression in Prox suggests that the Prox region may show a response to auxin that is distinct from the $\mathrm{AZ}$ and Dis regions. These different responses to auxin are likely to reflect the different gene expression patterns in each tissue. Because the auxin level determines the timing of onset of pedicel abscission [27], the auxin signaling genes found in this study, especially those expressed in AZ and Dis region, may be involved in preventing the onset of abscission.

\section{MADS box proteins may be key factors that determine the identities of pedicel regions}

Our results showed that despite their similar external appearances, the Prox and Dis regions in anthesis pedicels have distinct expression profiles. In particular, the Dis region is characterized by the specific expression of the genes related to floral organ development such as homologues of AP2 (SlAP2a) and MADS box genes AGL6 (BI203609), AP3 (TAP3), SEP1 (TM29 and SIMBP21) and SEP3 (TDR5), suggesting that Dis has floral organ like identity at the gene expression level (Table 3). By contrast, the Prox region cells specifically expressed a homologue of SOC1 (SIMBP14), which encodes another MADS box protein that regulates the transition from vegetative to reproductive growth $[62,63]$. The region-specific expression of transcription factor genes that determine distinct cell fates suggests that the Prox and Dis tissues have distinct developmental identities.

Our previous study indicated that the MADS box genes $M C$ and JOINTLESS, which are expressed throughout the pedicel tissues, regulate pedicel AZ development and also induce AZ specific expression of LeWUS, Bl, GOB and Ls [10]. These observations suggest that MADS box transcription factors may substantially contribute to specification of the identity of the pedicel regions. The MADS box proteins that are expressed in each pedicel region may form region-specific protein complexes and determine the identities of each region, similarly to the quartet model proposed in flower organ identification [93].

\section{Conclusion}

To unveil the transcriptional properties of tomato pedicels at the pre-abscission state, we analyzed the gene 
expression profiles of three flower pedicel regions, Prox, $\mathrm{AZ}$ and Dis. The gene expression data indicated that there are substantial differences between AZ and nonAZ tissues (Prox and Dis), and also between Prox and Dis. In particular, genes involved in auxin activity showed distinct expression patterns in the pedicel regions, suggesting that a gradient of auxin concentration may be formed throughout the pedicel regions and this auxin gradient may be one of the key factors affecting the distinct expression patterns in the pedicel tissues. These auxin-related genes may play a critical role in the regulation of timing of abscission. Various groups of transcription factors were also expressed in a regionspecific manner, and of these, different types of MADSbox transcription factor genes were found in different regions. For example, the Dis region cells express the MADS-box genes required for floral organ development, whereas the Prox region cells express another MADS-box gene regulating flowering. Several types of MADS-box protein complexes may form in the respective pedicel regions specifically to regulate gene expression, similarly to the floral quartet model. A couple of transcription factor genes associated with apical or axillary shoot meristem function were found to be expressed preferentially in the $\mathrm{AZ}$, indicating that shoot meristem cells and AZ cells may have common meristematic functions. Finally, the detailed gene expression analyses of $B l, G O B, L s$ and LeWUS suggest that these AZ specific transcription factor genes may be key factors responding to an abscission cue, although the regulatory pathways may be different between these four genes; $B l$ may be a positive regulator of abscission and the other three may be negative regulators.

In conclusion, this study identifies multiple differentially expressed factors that may be important in establishing and maintaining the properties of pre-abscission tomato pedicel $\mathrm{AZs}$, and provides insights into the transcriptional regulation of pre-abscission responses. Especially, comparative study of genes commonly expressed in both AZs and SAMs may provide a new aspect of the regulation in the abscission. In addition, the pedicel region specific MADS box transcription factors would be attractive candidates for the regulators determining pedicel tissue identities.

\section{Methods}

\section{Microarray experiments and data analysis}

Expression analyses were performed on total RNAs extracted from tomato (Solanum lycopersicum) cv. Ailsa Craig grown in soil in a growth room at $25^{\circ} \mathrm{C}$ with $16 \mathrm{~h}$ day length. Each pedicel region was carefully cut off using a sharp razor blade and subjected to analysis. For hybridization, we used the Agilent Tomato Gene Expression Microarray 44K (Agilent Technologies, Santa Clara CA, USA), which contains probes designed from the EST sequences deposited in three different databases,
GeneBank (GB accessions), TIGR (TA accessions) and the Tomato Gene Index (TC and NP accessions). Hybridization and signal detection was performed essentially as described previously [10]. Signal intensities were normalized by the per chip normalization method to the 75th percentile using GeneSpring software version 10.0 (Agilent Technologies). Data from outlier probes were removed if the signal was a non-uniform outlier, or if the signal was a population outlier. Data from three independently prepared samples were evaluated by a one-sample t-test with the $\log _{2}$-transformed signal ratios of each probe using $\mathrm{MeV}$ v4.6.2 software with the default setting using the options " $p$-values based on t-distribution" and "Just Alpha (no correction)" [94]. To annotate tomato ESTs whose sequences were used for microarray probes, we searched the Arabidopsis Information Resource protein database (TAIR9) by BLASTX with the expect value threshold at 0.01 . The ESTs for the microarray probes were assigned to the coding sequences (CDS) predicted by ITAG (version 2.3) via BLASTN searches with expect value threshold at $1 \mathrm{e}-10$ on the International Solanaceae Genomics project (SOL) genomics network website (http://solgenomics.net/). The complete microarray data set has been deposited at the Gene Expression Omnibus with accession number GSE39519 [NCBI GEO].

\section{RT-PCR and quantitative RT-PCR analysis}

First strand cDNAs for RT-PCR experiments were synthesized with the PrimeScript 1st strand cDNA Synthesis Kit (Takara Bio Inc., Otsu Shiga, Japan). The RT-PCR was performed using ExTaq polymerase (Takara Bio Inc.) following the manufacturer's instructions. Quantitative PCR amplification was carried out with the 7300 Real-Time PCR System (Applied Biosystems, Foster City, CA, USA) using THUNDERBIRD SYBR qPCR MIX (TOYOBO, Osaka, Japan). Relative quantification of the expression of each gene was performed using the $2^{-\Delta \Delta C T}$ method [95]. The SAND (SGN-U316474) gene was used as an internal control [96]. Oligonucleotides used for PCR are listed in Additional file 11.

\section{In situ hybridization}

Anthesis flower pedicels were fixed with formalin/acetic acid/alcohol (FAA), embedded in paraffin and then sectioned at $4 \mu \mathrm{m}$ thickness. Probe hybridization was performed according to the previously described method [97]. Color reactions were performed with NBT/BCIP. A control section was stained with hematoxylin and eosin stain. Each section was counterstained with Kernechtrot stain and mounted with CC/Mount (Sigma-Aldrich). To produce DIG-labeled RNA probes, cDNA fragments were PCR-amplified (oligonucleotides listed in Additional file 11) and cloned into pSPT19 (Roche); DIG-labeled RNAs were synthesized with T7 RNA polymerase. 


\section{Additional files}

Additional file 1: Genes up-regulated in AZ compared with Prox. Additional file 2: Genes up-regulated in $A Z$ compared with Dis. Additional file 3: Validation of the microarray data by RT-PCR assays on genes that exhibited $A Z$ preferential expression by the microarray assays. Transcript levels of 10 genes in the pedicel regions, $A Z$, Prox and Dis, were compared for the microarray and RT-PCR assays. The results obtained by the two methods showed good consistency for all the examined genes. As an internal control (Ctrl) for the RT-PCR assays, SAND (SGN-U316474) was used [96].

Additional file 4: Genes down-regulated in AZ compared with nonAZ (Prox and Dis).

Additional file 5: Genes up-regulated in Prox compared with Dis. Additional file 6: Genes up-regulated in Dis compared with Prox. Additional file 7: Validation of the microarray data by RT-PCR on genes differentially expressed between Prox and Dis. Transcript levels of 11 genes in the pedicel regions, AZ, Prox and Dis, were compared with the microarray assays and RT-PCR assays. The results obtained by the two methods showed good consistency for all the examined genes. As an internal control (Ctrl) for the RT-PCR assays, SAND (SGN-U316474) was used [96].

Additional file 8: Frequency of flower pedicel abscission after removal of the flower. Anthesis flowers were removed from the pedicels to induce abscission and then the number of abscised pedicels was counted. In total, 206 flower pedicels were used for the analysis.

Additional file 9: Expression of $B l, G O B$, Ls, LeWUS and TAPG4 in the $\mathbf{A Z}$ of a tomato flower pedicel at anthesis. When tissue sections of the AZ of a flower pedicel at anthesis were hybridized with the DIGlabeled antisense probes for BI, GOB, LS LeWUS and TAPG4, the hybridization signals were detected in tube-like vascular cells but no specific signals were detected when their sense probe were examined. The signals for each gene are indicated by arrowheads.

Additional file 10: The expression patterns of TA50096_4081 (an ARF9 homologue) and AK319758 (an IAA29 homologue) in tomato flower anthesis pedicels. The transcript level of AK319758 was the highest in Dis and decreased gradually toward Prox; TA50096_4081 was significantly higher in Prox compared to Dis. The expression signal intensity was detected by microarray assays and error bars indicate standard deviation of biological triplicates for the assay.

Additional file 11: Sequences of primers used in this study.

\section{Competing interests}

The authors declare that they have no competing interests.

\section{Authors' contributions}

TN and YI designed the research; TN performed the research and analyzed data; MF contributed to the microarray data analysis; YS contributed to the sample preparation; TN and YI wrote the paper. All authors read and approved the final draft.

\section{Acknowledgements}

The authors thank Ms. Akemi Koma for her technical assistance. This work was supported by the Program for Promotion of Basic and Applied Researches for Innovations in Bio-oriented Industry (BRAIN) to Yl.

\section{Received: 20 July 2012 Accepted: 4 March 2013}

Published: 9 March 2013

\section{References}

1. Roberts JA, Elliott KA, Gonzalez-Carranza ZH: Abscission, dehiscence, and other cell separation processes. Annu Rev Plant Biol 2002, 53:131-158.

2. Addicot FT: Abscission. Berkeley, CA: University of California Press; 1982.

3. van Nocker S: Development of the abscission zone. Stewart Postharvest Review 2009, 5(1):5.

4. Doebley J: The genetics of maize evolution. Annu Rev Genet 2004, 38:37-59.
5. Tanno K, Willcox G: How fast was wild wheat domesticated? Science 2006, 311(5769):1886-1886.

6. Li C, Zhou A, Sang T: Rice domestication by reducing shattering. Science 2006, 311(5769):1936-1939.

7. Patterson SE: Cutting loose. Abscission and dehiscence in Arabidopsis. Plant Physiol 2001, 126(2):494-500.

8. Butler L: Inherited characters in the tomato. II. Jointless pedicel. J Hered 1936, 27:25-26.

9. Rick CM: Genetics and systematic studies on accessions of Lycopersicon from the Galapagos Islands. Ann J Bot 1956, 43:687-696.

10. Nakano T, Kimbara J, Fujisawa M, Kitagawa M, Ihashi N, Maeda H, Kasumi T, Ito Y: MACROCALYX and JOINTLESS interact in the transcriptional regulation of tomato fruit abscission zone development. Plant Physiol 2012, 158(1):439-450.

11. Mao L, Begum D, Chuang HW, Budiman MA, Szymkowiak EJ, Irish EE, Wing RA: JOINTLESS is a MADS-box gene controlling tomato flower abscission zone development. Nature 2000, 406(6798):910-913.

12. Schumacher K, Schmitt T, Rossberg M, Schmitz C, Theres K: The Lateral suppressor (Ls) gene of tomato encodes a new member of the VHIID protein family. Proc Natl Acad Sci USA 1999, 96(1):290-295.

13. Budiman MA, Chang SB, Lee S, Yang TJ, Zhang HB, de Jong H, Wing RA Localization of jointless-2 gene in the centromeric region of tomato chromosome 12 based on high resolution genetic and physical mapping. Theor App/ Genet 2004, 108(2):190-196.

14. Vrebalov J, Ruezinsky D, Padmanabhan V, White R, Medrano D, Drake R, Schuch W, Giovannoni J: A MADS-box gene necessary for fruit ripening at the tomato ripening-inhibitor (rin) locus. Science 2002, 296(5566):343-346.

15. Ogawa M, Kay P, Wilson S, Swain SM: ARABIDOPSIS DEHISCENCE ZONE POLYGALACTURONASE1 (ADPG1), ADPG2, and QUARTET2 are Polygalacturonases required for cell separation during reproductive development in Arabidopsis. Plant Cell 2009, 21(1):216-233.

16. Pinyopich A, Ditta GS, Savidge B, Liljegren SJ, Baumann E, Wisman E, Yanofsky MF: Assessing the redundancy of MADS-box genes during carpel and ovule development. Nature 2003, 424(6944):85-88.

17. Mckim SM, Stenvik GE, Butenko MA, Kristiansen W, Cho SK, Hepworth SR, Aalen RB, Haughn GW: The BLADE-ON-PETIOLE genes are essential for abscission zone formation in Arabidopsis. Development 2008, 135(8):1537-1546.

18. Zhou Y, Lu D, Li C, Luo J, Zhu BF, Zhu J, Shangguan Y, Wang Z, Sang T, Zhou $B$, et al: Genetic control of seed shattering in rice by the APETALA2 transcription factor SHATTERING ABORTION1. Plant Cell 2012, 24(3):1034-1048.

19. Konishi S, Izawa T, Lin SY, Ebana K, Fukuta Y, Sasaki T, Yano M: An SNP caused loss of seed shattering during rice domestication. Science 2006, 312(5778):1392-1396.

20. Lin ZW, Li XR, Shannon LM, Yeh CT, Wang ML, Bai GH, Peng Z, Li JR, Trick $\mathrm{HN}$, Clemente TE, et al: Parallel domestication of the Shattering1 genes in cereals. Nat Genet 2012, 44(6):720-724.

21. Ji H, Kim SR, Kim YH, Kim H, Eun MY, Jin ID, Cha YS, Yun DW, Ahn BO, Lee $M C$, et al: Inactivation of the CTD phosphatase-like gene OSCPL1 enhances the development of the abscission layer and seed shattering in rice. Plant J 2010, 61(1):96-106.

22. Taylor JE, Whitelaw CA: Signals in abscission. New Phytol 2001, 151(2):323-339.

23. Lashbrook CC, Giovannoni JJ, Hall BD, Fischer RL, Bennett AB: Transgenic analysis of tomato endo-beta-1,4-glucanase gene function. Role of cel1 in floral abscission. Plant J 1998, 13(3):303-310.

24. Leslie ME, Lewis MW, Liljegren SJ: Organ Abscission. In Plant Cell Separation and Adhesion, Annual Plant Reviews. volume 25. Edited by Roberts JA Gonzalez-Carranza ZH. Oxford, UK: Blackwell Publishing; 2007.

25. Belfield EJ, Ruperti B, Roberts JA, McQueen-Mason S: Changes in expansin activity and gene expression during ethylene-promoted leaflet abscission in Sambucus nigra. J Exp Bot 2005, 56(413):817-823.

26. Cho HT, Cosgrove DJ: Altered expression of expansin modulates leaf growth and pedicel abscission in Arabidopsis thaliana. Proc Natl Acad Sci USA 2000, 97(17):9783-9788.

27. Meir S, Philosoph-Hadas S, Sundaresan S, Selvaraj KSV, Burd S, Ophir R, Kochanek B, Reid MS, Jiang CZ, Lers A: Microarray analysis of the abscission-related transcriptome in the tomato flower abscission zone in response to auxin depletion. Plant Physiol 2010, 154(4):1929-1956.

28. Cai SQ, Lashbrook CC: Stamen abscission zone transcriptome profiling reveals new candidates for abscission control: Enhanced retention of 
floral organs in Transgenic plants overexpressing Arabidopsis ZINC FINGER PROTEIN2. Plant Physiol 2008, 146(3):1305-1321.

29. Agusti J, Merelo P, Cercos M, Tadeo FR, Talon M: Ethylene-induced differential gene expression during abscission of citrus leaves. J Exp Bot 2008, 59(10):2717-2733.

30. Reinhardt D, Frenz M, Mandel T, Kuhlemeier C: Microsurgical and laser ablation analysis of interactions between the zones and layers of the tomato shoot apical meristem. Development 2003, 130(17):4073-4083.

31. Berger $Y$, Harpaz-Saad $S$, Brand $A$, Melnik $H$, Sirding $N$, Alvarez JP, Zinder $M$, Samach A, Eshed Y, Ori N: The NAC-domain transcription factor GOBLET specifies leaflet boundaries in compound tomato leaves. Development 2009, 136(5):823-832.

32. Schmitz $G$, Tillmann $E$, Carriero F, Fiore $C$, Cellini F, Theres $K$ : The tomato Blind gene encodes a MYB transcription factor that controls the formation of lateral meristems. Proc Natl Acad Sci USA 2002, 99(2):1064-1069.

33. Roberts JA, Schindler CB, Tucker GA: Ethylene-promoted tomato flower abscission and the possible involvement of an inhibitor. Planta 1984, 160(2):159-163.

34. Tabuchi T: Comparison on the development of abscission zones in the pedicels between two tomato cultivars. J Jpn Soc Hortic Sci 1999, 68(5):993-999.

35. Kerstetter RA, LaudenciaChingcuanco D, Smith LG, Hake S: Loss-of-function mutations in the maize homeobox gene, knotted1, are defective in shoot meristem maintenance. Development 1997, 124(16):3045-3054.

36. Shi CL, Stenvik GE, Vie AK, Bones AM, Pautot V, Proveniers M, Aalen RB, Butenko MA: Arabidopsis class I KNOTTED-like homeobox proteins Act downstream in the IDA-HAE/HSL2 floral abscission signaling pathway. Plant Cell 2011, 23(7):2553-2567.

37. Wang $X Q, X u$ WH, Ma LG, Fu ZM, Deng XW, Li JY, Wang YH: Requirement of KNAT1/BP for the development of abscission zones in Arabidopsis thaliana. J Integr Plant Biol 2006, 48(1):15-26.

38. Wang L, Hua DP, He JN, Duan Y, Chen ZZ, Hong XH, Gong ZZ: Auxin response Factor2 (ARF2) and its regulated homeodomain gene HB33 mediate abscisic acid response in arabidopsis. PLoS Genet 2011, 7(7):e1002172.

39. Gallavotti A, Malcomber S, Gaines C, Stanfield S, Whipple C, Kellogg E, Schmidt RJ: BARREN STALK FASTIGIATE1 is an AT-hook protein required for the formation of maize ears. Plant Cell 2011, 23(5):1756-1771.

40. Lim PO, Kim Y, Breeze E, Koo JC, Woo HR, Ryu JS, Park DH, Beynon J, Tabrett A, Buchanan-Wollaston $V$, et al: Overexpression of a chromatin architecture-controlling AT-hook protein extends leaf longevity and increases the post-harvest storage life of plants. Plant J 2007, 52(6):1140-1153.

41. Matsushita A, Furumoto T, Ishida S, Takahashi Y: AGF1, an AT-hook protein, is necessary for the negative feedback of AtGA3ox1 encoding GA 3-oxidase. Plant Physiol 2007, 143(3):1152-1162.

42. Komatsu M, Chujo A, Nagato Y, Shimamoto K, Kyozuka J: FRIZZY PANICLE is required to prevent the formation of axillary meristems and to establish floral meristem identity in rice spikelets. Development 2003, 130(16):3841-3850.

43. Gutterson N, Reuber TL: Regulation of disease resistance pathways by AP2/ERF transcription factors. Curr Opin Plant Biol 2004, 7(4):465-471.

44. Shinozaki K, Yamaguchi-Shinozaki K: Molecular responses to dehydration and low temperature: differences and cross-talk between two stress signaling pathways. Curr Opin Plant Biol 2000, 3(3):217-223.

45. Broun P, Poindexter P, Osborne E, Jiang CZ, Riechmann JL: WIN1, a transcriptional activator of epidermal wax accumulation in Arabidopsis. Proc Natl Acad Sci USA 2004, 101(13):4706-4711.

46. Wang S, Chang Y, Guo J, Chen JG: Arabidopsis ovate family protein 1 is a transcriptional repressor that suppresses cell elongation. Plant $J$ 2007, 50(5):858-872.

47. Liu JP, Van Eck J, Cong B, Tanksley SD: A new class of regulatory genes underlying the cause of pear-shaped tomato fruit. Proc Natl Acad Sci USA 2002, 99(20):13302-13306.

48. Staswick PE, Serban B, Rowe M, Tiryaki I, Maldonado MT, Maldonado MC, Suza W: Characterization of an Arabidopsis enzyme family that conjugates amino acids to indole-3-acetic acid. Plant Cell 2005, 17(2):616-627.

49. Yang Y, Xu R, Ma CJ, Vlot AC, Klessig DF, Pichersky E: Inactive methyl indole-3-acetic acid ester can be hydrolyzed and activated by several esterases belonging to the AtMES esterase family of Arabidopsis. Plant Physiol 2008, 147(3):1034-1045.

50. Woodward AW, Bartel B: Auxin: Regulation, action, and interaction. Ann Bot 2005, 95(5):707-735.

51. Kalaitzis $\mathrm{P}$, Solomos $\mathrm{T}$, Tucker ML: Three different polygalacturonases are expressed in tomato leaf and flower abscission, each with a different temporal expression pattern. Plant Physiol 1997, 114(3):1314-1314.

52. Jiang CZ, Lu F, Imsabai W, Meir S, Reid MS: Silencing polygalacturonase expression inhibits tomato petiole abscission. J Exp Bot 2008, 59(4):973-979.

53. Hong SB, Sexton R, Tucker ML: Analysis of gene promoters for two tomato polygalacturonases expressed in abscission zones and the stigma. Plant Physiol 2000, 123(3):869-881.

54. Henry EW, Valdovinos JG, Jensen TE: Peroxidases in tobacco abscission zone tissue: Il. Time course studies of peroxidase activity during ethylene-induced abscission. Plant Physiol 1974, 54(2):192-196.

55. Clarke HRG, Davis JM, Wilbert SM, Bradshaw HD, Gordon MP: Woundinduced and developmental activation of a poplar tree chitinase gene promoter in transgenic tobacco. Plant Mol Biol 1994, 25(5):799-815.

56. Lotan T, Ori N, Fluhr R: Pathogenesis-related proteins are developmentally regulated in tobacco flowers. Plant Cell 1989, 1(9):881-887.

57. Jensen TE, Valdovinos JG: Fine structure of abscission zones.l. Abscission zones of pedicels of tobacco and tomato flowers at anthesis. Planta 1967, 77(4):298-318.

58. Lashbrook CC, Gonzalez-Bosch C, Bennett AB: Two divergent endo-beta-1,4glucanase genes exhibit overlapping expression in ripening fruit and abscising flowers. Plant Cell 1994, 6(10):1485-1493.

59. Bar-Dror T, Dermastia M, Kladnik A, Znidaric MT, Novak MP, Meir S, Burd S, Philosoph-Hadas S, Ori N, Sonego L, et al: Programmed cell death occurs asymmetrically during abscission in tomato. Plant Cell 2011, 23(11):4146-4163.

60. Jofuku KD, Denboer BGW, Vanmontagu M, Okamuro JK: Control of arabidopsis flower and seed development by the homeotic gene Apetala2. Plant Cell 1994, 6(9):1211-1225.

61. Chung MY, Vrebalov J, Alba R, Lee J, McQuinn R, Chung JD, Klein P, Giovannoni J: A tomato (Solanum lycopersicum) APETALA2/ERF gene, SIAP2a, is a negative regulator of fruit ripening. Plant $J$ 2010, 64(6):936-947.

62. Lee J, Lee I: Regulation and function of $\mathrm{SOC} 1$, a flowering pathway integrator. J Exp Bot 2010, 61(9):2247-2254.

63. Melzer S, Lens F, Gennen J, Vanneste S, Rohde A, Beeckman T: Floweringtime genes modulate meristem determinacy and growth form in Arabidopsis thaliana. Nat Genet 2008, 40(12):1489-1492.

64. Ulmasov T, Hagen G, Guilfoyle TJ: Activation and repression of transcription by auxin-response factors. Proc Natl Acad Sci USA 1999, 96(10):5844-5849.

65. Ellis CM, Nagpal P, Young JC, Hagen G, Guilfoyle TJ, Reed JW: AUXIN RESPONSE FACTOR1 and AUXIN RESPONSE FACTOR2 regulate senescence and floral organ abscission in Arabidopsis thaliana. Development 2005, 132(20):4563-4574.

66. Kunihiro A, Yamashino T, Nakamichi N, Niwa Y, Nakanishi H, Mizuno T: PHYTOCHROME-INTERACTING FACTOR 4 and 5 (PIF4 and PIF5) activate the homeobox ATHB2 and auxin-inducible IAA29 genes in the coincidence mechanism underlying photoperiodic control of plant growth of arabidopsis thaliana. Plant Cell Physiol 2011, 52(8):1315-1329.

67. Shin R, Burch AY, Huppert KA, Tiwari SB, Murphy AS, Guilfoyle TJ, Schachtman DP: The Arabidopsis transcription factor MYB77 modulates auxin signal transduction. Plant Cell 2007, 19(8):2440-2453.

68. Xie Q, Frugis G, Colgan D, Chua NH: Arabidopsis NAC1 transduces auxin signal downstream of TIR1 to promote lateral root development. Genes Dev 2000, 14(23):3024-3036.

69. Siegfried KR, Eshed Y, Baum SF, Otsuga D, Drews GN, Bowman JL: Members of the YABBY gene family specify abaxial cell fate in Arabidopsis. Development 1999, 126(18):4117-4128.

70. Li H, Johnson P, Stepanova A, Alonso JM, Ecker JR: Convergence of signaling of differential cell growth pathways in the control in Arabidopsis. Dev Cell 2004, 7(2):193-204.

71. Boeglin WE, Itoh A, Zheng Y, Coffa G, Howe GA, Brash AR: Investigation of substrate binding and product stereochemistry issues in two linoleate 9-lipoxygenases. Lipids 2008, 43(11):979-987. 
72. Hwang IS, Hwang BK: The pepper 9-lipoxygenase gene CaLOX1 functions in defense and cell death responses to microbial pathogens. Plant Physiol 2010, 152(2):948-967.

73. Vicente J, Cascon T, Vicedo B, Garcia-Agustin P, Hamberg M, Castresana C: Role of 9-lipoxygenase and alpha-dioxygenase oxylipin pathways as modulators of local and systemic defense. Mol Plant 2012, 5(4):914-928.

74. Roxrud I, Lid SE, Fletcher JC, Schmidt ED, Opsahl-Sorteberg HG: GASA4, one of the 14-member Arabidopsis GASA family of small polypeptides, regulates flowering and seed development. Plant Cell Physiol 2007, 48(3):471-483.

75. Taylor BH, Scheuring CF: A molecular marker for lateral root initiation the Rsi-1 gene of tomato (lycopersicon-esculentum mill) is activated in early lateral root primordia. Mol Gen Genet 1994, 243(2):148-157.

76. Rutjens B, Bao DP, van Eck-Stouten E, Brand M, Smeekens S, Proveniers M: Shoot apical meristem function in Arabidopsis requires the combined activities of three BEL1-like homeodomain proteins. Plant J 2009, 58(4): 641-654.

77. Hay A, Tsiantis M: KNOX genes: versatile regulators of plant development and diversity. Development 2010, 137(19):3153-3165.

78. Goldshmidt A, Alvarez JP, Bowman JL, Eshed Y: Signals derived from YABBY gene activities in organ primordia regulate growth and partitioning of Arabidopsis shoot apical meristems. Plant Cell 2008, 20(5):1217-1230.

79. Barton MK: Twenty years on: The inner workings of the shoot apical meristem, a developmental dynamo. Dev Biol 2010, 341(1):95-113.

80. Tabuchi T, Arai N: Formation of the secondary cell division zone in tomato pedicels at different fruit growing stages. J Jan Soc Hortic Sci 2000, 69(2):156-160.

81. Lenhard M, Jurgens G, Laux T: The WUSCHEL and SHOOTMERISTEMLESS genes fulfil complementary roles in Arabidopsis shoot meristem regulation. Development 2002, 129(13):3195-3206.

82. Long JA, Moan El, Medford Jl, Barton MK: A member of the KNOTTED class of homeodomain proteins encoded by the STM gene of Arabidopsis. Nature 1996, 379(6560):66-69.

83. Mayer KF, Schoof H, Haecker A, Lenhard M, Jurgens G, Laux T: Role of WUSCHEL in regulating stem cell fate in the Arabidopsis shoot meristem. Cell 1998, 95(6):805-815.

84. Raman S, Greb T, Peaucelle A, Blein T, Laufs P, Theres K: Interplay of miR164, CUP-SHAPED COTYLEDON genes and LATERAL SUPPRESSOR controls axillary meristem formation in Arabidopsis thaliana. Plant J 2008, 55(1):65-76

85. Muller D, Schmitz G, Theres K: Blind homologous R2R3 Myb genes control the pattern of lateral meristem initiation in Arabidopsis. Plant Cell 2006, 18(3):586-597.

86. Tabuchi T, Ito $\mathrm{S}$, Arai N: Anatomical studies of the abscission process in the tomato pedicels at flowering stage. J Jpn Soc Hortic Sci 2001, 70(1):63-65.

87. Sexton R, Redshaw AJ: The role of cell expansion in the abscission of impatients-sultani leaves. Ann Bot 1981, 48(5):745-756.

88. Peaucelle A, Morin H, Traas J, Laufs P: Plants expressing a miR164-resistant CUC2 gene reveal the importance of post-meristematic maintenance of phyllotaxy in Arabidopsis. Development 2007, 134(6):1045-1050.

89. Greb T, Clarenz O, Schafer E, Muller D, Herrero R, Schmitz G, Theres K: Molecular analysis of the LATERAL SUPPRESSOR gene in Arabidopsis reveals a conserved control mechanism for axillary meristem formation. Gene Dev 2003, 17(9):1175-1187.

90. Yadav RK, Perales M, Gruel J, Girke T, Jonsson H, Reddy GV: WUSCHEL protein movement mediates stem cell homeostasis in the Arabidopsis shoot apex. Gene Dev 2011, 25(19):2025-2030.

91. Ludwig-Muller J: Auxin conjugates: their role for plant development and in the evolution of land plants. J Exp Bot 2011, 62(6):1757-1773.

92. Guilfoyle TJ, Hagen G: Auxin response factors. Curr Opin Plant Biol 2007, 10(5):453-460.

93. Theissen G, Saedler H: Plant biology - Floral quartets. Nature 2001, 409(6819):469-471.

94. Saeed Al, Bhagabati NK, Braisted JC, Liang W, Sharov V, Howe EA, Li J, Thiagarajan M, White JA, Quackenbush J: TM4 microarray software suite. Methods Enzymol 2006, 411:134-193.

95. Livak KJ, Schmittgen TD: Analysis of relative gene expression data using real-time quantitative PCR and the 2(T)(-Delta Delta C) method. Methods 2001, 25(4):402-408.
96. Exposito-Rodriguez M, Borges AA, Borges-Perez A, Perez JA: Selection of internal control genes for quantitative real-time RT-PCR studies during tomato development process. BMC Plant Biol 2008, 8:131.

97. Kikawada T, Saito A, Kanamori Y, Nakahara Y, Iwata Kl, Tanaka D, Watanabe M, Okuda T: Trehalose transporter 1, a facilitated and high-capacity trehalose transporter, allows exogenous trehalose uptake into cells. Proc Natl Acad Sci USA 2007, 104(28):11585-11590.

doi:10.1186/1471-2229-13-40

Cite this article as: Nakano et al:: Expression profiling of tomato preabscission pedicels provides insights into abscission zone properties including competence to respond to abscission signals. BMC Plant Biology 2013 13:40

\section{Submit your next manuscript to BioMed Central and take full advantage of:}

- Convenient online submission

- Thorough peer review

- No space constraints or color figure charges

- Immediate publication on acceptance

- Inclusion in PubMed, CAS, Scopus and Google Scholar

- Research which is freely available for redistribution

Submit your manuscript at www.biomedcentral.com/submit
C Biomed Central 